\title{
Ekspansi Kerajaan Gowa-Tallo Ke Limae Ajatappareng Abad XVI
}

\author{
Sahrul Habrianto. S, M. Saleh Madjid, M. Rasyid Ridha \\ Prodi Pendidikan Sejarah Fakultas Ilmu Sosial Universitas Negeri Makassar \\ sahrul.madridtista@gmail.com
}

\begin{abstract}
Abstrak
Penelitian ini bertujuan untuk mengetahui tentang ekspansi kerajaan Gowa-Tallo ke Limae Ajatappareng dengan menguraikan gambaran umum Gowa-Tallo dan Limae Ajatappareng, latar belakang penyebab terjadinya ekspansi, bentuk-bentuk ekspansi, serta dampak ekspansi bagi masing-masing pihak. Hasil penelitian menunjukkan bahwa, Ekspansi kerajaan GowaTallo ke Limae Ajatappareng dimulai pada masa pemerintahan Karaeng Tunipallangga (15461565) yang berawal dari keinginan untuk mengembangkan perekonomian dan perdagangan maritim. Ekspansi ini bukan hanya semata-mata ekspansi fisik, namun juga dalam bentuk penguasaan perekonomian dan pertalian darah melalui perkawinan politik. Ekspansi ini bertujuan agar bandar kerajaan Gowa-Tallo dapat berkembang mengalahkan pesaingnya sehingga mengindikasikan bahwa motif utama dari ekspansi ini adalah terkait dengan masalah perekonomian. Berdasarkan hasil penelitian, maka dapat disimpulkan bahwa pada akhirnya kerajaan Gowa-Tallo berhasil mengamankan suplai bahan pangan, serta berhasil memajukan bandar kerajaannya. Keberhasilan ekspansi ini ditandai dengan semakin ramainya bandar kerajaan Gowa-Tallo yang bertahan hingga puluhan tahun sebelum penguasaan oleh VOC pada abad XVII. Penelitian ini menggunakan metodologi penelitian sejarah yang meliputi heuristik yaitu tahapan pengumpulan data, kritik sumber yang bertujuan untuk menilai sumber yang tersedia, interpretasi yaitu menafsirkan sumber dan data yang tersedia, serta historiografi sebagai langkah akhir yakni menyajikan data menjadi satu tulisan sejarah utuh. Metode pengumpulan data yaitu dengan mengumpulkan sumber-sumber pustaka baik buku ataupun arsip-arsip serta wawancara terhadap peneliti-peneliti yang memiliki kajian yang berkaitan sebagai pelengkap dari data-data yang telah diambil sebelumnya.
\end{abstract}

\section{Kata Kunci : Ekspansi, Limae Ajatappareng, Gowa-Tallo}

\begin{abstract}
This research aims to know about the expansion of Gowa-Tallo kingdom to Limae Ajatappareng by elaborating the overview of Gowa-Tallo and Limae Ajatappareng, the background of the cause of expansion, expansion forms, and impact Expansion for each party. The results showed that, Gowa-Tallo Kingdom expansion to Limae Ajatappareng began during the reign of Karaeng Tunipallangga (1546-1565) which originated from the desire to develop the economy and maritime trade. This expansion is not merely a physical expansion, but also in the form of economic mastery and blood connection through political marriage. This expansion is aimed at making the Gowa-Tallo royal port able to develop to defeat its competitors, thus indicating that the main motive of this expansion is related to economic problems. Based on the research, it is concluded that the Gowa-Tallo kingdom was finally able to secure the supply of food, and managed to advance its royal port. The success of the expansion was characterized by the growing port of Gowa-Tallo, which lasted for decades before mastering by VOC in the 17th century. This research uses a history research methodology which includes a heuristic that is the stage of data collection, criticism of sources aimed at assessing the available sources, interpretation of which is interpreting the source and
\end{abstract}

Vol. 6, No.3, Desember 2019, 16-28 | 16 
data available, as well as historiography as the final step of presenting the data into a single historical inscription intact. The method of data collection is by collecting the library resources both books and archives as well as interviews to researchers who have related studies as a complement of the data that has been taken before.

\section{Keywords : Expansion, Limae Ajatappareng, Gowa-Tallo}

\section{A. Pendahuluan}

Indonesia pada masa lampau memiliki banyak kerajaan-kerajaan besar dan penting dalam sejarah Indonesia.Salah satu indikator untuk mengukur besarnya suatu kerajaan adalah dengan melihat hegemoninya terhadap kerajaan-kerajaan di sekitarnya maupun yang berada di titik terjauh dari pusat pemerintahannya. Kerajaan-kerajaan besar di Nusantara pada masanya yakni Kerajaan Sriwijaya, Majapahit, Kutai Kartanegara, dan kerajaan-kerajaan lainnya. Kerajaankerajaan pada hakikatnya berusaha untuk memperluas dan memperbesar kerajaannya ataupun peningkatan perekonomian kerajaannya. Maka dalam hal ini, kerajaankerajaan saling berusaha menancapkan kekuasan dan hegemoninya ke kerajaankerajaan terdekat yang kekuatannya relatif lebih kecil maupun pesaing terkuatnya.

Ekspansi adalah "to increase in size, number, or importance, or to make something increase" (upaya untuk bertambah dalam segi ukuran, banyaknya, maupun kepentingan atau dengan kata lain membuat suatu hal meningkat atau bertambah besar). (Anon., 2019) Perlu dipahami bahwa ekspansi bukan hanya terbatas pada perluasan wilayah melalui kekuatan militer tetapi juga dapat dilakukan dengan cara perluasan pengaruh maupun perluasan wilayah perekonomian. Ekspansi sendiri seolah menjadi tindakan umum bagi suatu kerajaan atau suatu bangsa untuk menunjukkan hegemoninya dan kekuatan pengaruhnya terhadap kerajaan lain.

Jika merujuk pada batasan spasial Sulawesi bagian selatan maka dapat dilihat beragam invasi dan ekspansi yang terjadi bahkan di awal kemunculan kerajaankerajaan di Sulawesi Selatan pada abad ke XV. Kerajaan Gowa pada awalnya bukan merupakan kerajaan yang diperhitungkan keberadaannya, hal ini dikarenakan kerajaan Gowa masih bersifat agraris. Baru pada masa pemerintahan Raja Gowa ke-IX Karaeng Tumapa'risi' kallonna pada abad ke-16 pusat pemerintahan dipindahkan ke Somba Opu, yang berada di sekitar muara sungai Jeneberang. (Kila, 2004). Keputusan yang kemudian berdampak besar bagi kemajuan kerajaan Gowa-Tallo.

Setelah berpindah pusat pemerintahan dan kerajaan yang lebih berorientasi pada kegiatan maritim, maka kerajaan Gowa mulai banyak dikenal oleh pedagang dari luar.Tumapa'risi Kallonna juga menjadi pemrakarsa bersatunya dua kerajaan yakni Gowa dan Tallo dengan konsep "Dua raja tetapi satu rakyat”.Pada masa Tumapa'risi Kallonna pula kerajaan Gowa melakukan kontak lebih intens dengan kerajaankerajaan anggota konfederasi Ajatappareng. (Andaya, 2004).

Konfederasi Ajatappareng terbentuk berdasarkan keinginan dari para pembesar kerajaan di Ajatappareng untuk meningkatkan taraf ekonomi dan dalam urusan perpolitikan. Kerajaan Gowa-Tallo memiliki hubungan militer dengan anggota kerajaan di Konfederasi Limae Ajatappareng. Selain itu, kerajaan GowaTallo juga memiliki hubungan-hubungan lain seperti hubungan kekerabatan melalui pernikahan dan hubungan perekonomian terutama dikarenakan oleh Suppa yang mampu menjadi bandar niaga besar dan Sidenreng Rappang yang kaya akan sumber daya alam. (Makmur, 2015) Hal inilah yang menjadi dasar hubungan terus menerus antara kerajaan Gowa-Tallo dengan Konfederasi Ajatappareng.

Melihat kondisi generasi muda yang untuk saat ini seakan buta akan sejarah, terutama menyangkut sejarah kelokalan. 
Maka tulisan ini diharap dapat menjadi jembatan antara rasa keingintahuan dengan generasi berikutnya yang semoga saja selalu ingin menambah pengetahuannya mengenai sejarah, terutama sejarah lokal Sulawesi Selatan.

Berbeda dengan tulisan-tulisan dari penelitian-penelitian mengenai Limae Ajatappareng lainnya, tulisan ini lebih berfokus pada kegiatan Ekspansi Kerajaan Gowa-Tallo ke Limae Ajatappareng yang terjadi pada abad ke-16.

\section{B. Metode Penelitian}

Setiap penelitian adalah deskripsi secara cermat dan didasarkan atas teori dan metode. Secara umum metode dianggap sebagai cara-cara strategis untuk memahami realitas, langkah-langkah sistematis untuk memecahkan rangkaian sebab akibat berikutnya. Penelitian dari kata dasar "teliti" didefinisikan sebagai kegiatan pengumpulan dan pengolahan data yang disajikan secara sistematis dan objektif.

\section{Heuristik}

Heuristik artinya mencari dan mengumpulkan sumber-sumber sejarah yang terkait dengan topik penelitian. Dapat juga diartikan sebagai kegiatan berupa penghimpunan jejak-jejak masa lampau, yakni peninggalan sejarah atau sumber apa saja yang dapat dijadikan informasi dalam pengertian studi sejarah. (Sejarah, 2013). Dalam penelitian untuk tulisan ini dilakukan dalam dua jenis pendekatan yakni:

\section{a. Studi Kepustakaan}

Studi kepustakaan pada tulisan ini dijadikan sebagai sumber utama. Studi kepustakaan digunakan karena mengingat batasan temporal tulisan ini sudah sangat lampau sehingga sudah tidak memungkinkan untuk melakukan observasi langsung. Namun, dalam studi kepustakaan juga butuh kritik yang digunakan untuk menguji kebenaran data yang diperoleh melalui studi kepustakaan yang akan dibahas di bagian lain tulisan ini. Sumbersumber yang digunakan yaitu Lontara'yang relevan dengan kajian yang diteliti, seperti
Lontara' Attoriolong Suppa dan Sawitto dan Lontara We Lampeweluwa serta buku Stephen C. Druce yang berjudul The Lands West Of The Lakes : A history of the Ajatappareng kingdom of south Sulawesi 1200 to $1600 C E$ dan produkproduk akademis yang juga relevan seperti Tesis Burhanuddin Pabitjara "Persekutuan Limae Ajatappareng Abad XVI, jurnal penelitian serta sumber daring.

Perbedaan antara metode studi kepustakaan dengan metode lapangan tidak jelas garis pembedanya. Metode lapangan juga melakukan pengumpulan data melalui perpustakaan. Secara singkat, penggunaan istilah metode lapangan dengan metode pustaka semata-mata didasarkan atas dominasinya masing-masing. Oleh karena itulah, studi pustaka terhadap penelitian yang didominasi oleh pengumpulan data nonlapangan sekaligus meliputi objek yang diteliti dan data yang digunakan untuk membicarakannya, sebagai objek primer sekaligus sekunder. (Ratna, 2010).

\section{b. Wawancara}

Teknik wawancara digunakan sebagai pelengkap dalam tulisan ini. Wawancara dilakukan terhadap narasumber yang dianggap kredibel dan memiliki kompetensi mengenai tulisan ini. Dalam hal ini penulis mencoba meminta masukan dan pemahaman dari ayahanda Drs. Burhanuddin Pabitjara yang juga melakukan penelitian dan penulisan mengenai Limae Ajatappareng dalam bentuk Skripsi dan Tesis.

\section{Kritik}

Langkah selanjutnya setelah melakukan pengumpulan data-data awal yakni melakukan kritik. Hasil penelitian ataupun studi sejarah yang akademis ataupun kritis memerlukan fakta-fakta yang telah teruji. Oleh karena itu, data-data yang diperoleh melalui tahapan heuristik harus terlebih dahulu dikritik atau disaring sehingga diperoleh fakta-fakta yang seobjektif mungkin. Kritik tersebut berupa kritik ekstern dan kritik intern. Dilakukan ketika dan sesudah pengumpulan data berlangsung. 


\section{a. Kritik ekstern}

Kritik ekstern dilakukan guna mengkaji keaslian sumber sejarah. Keaslian yang dimaksud adalah asli dan bukan tiruan, sumber tersebut dalam arti belum berubah. Sebagai contoh, Lontara' We Lampeweluwa yang ditulis sejak ratusan tahun yang lalu dan masih dapat dipastikan keasliannya. Sedangkan pada metode wawancara dimana informan haruslah kredibel dan mampu dipertanggungjawabkan informasinya kala memberikan keterangan.

\section{b. Kritik intern}

Kritik Intern terhadap sumber tertulis terutama dilakukan dengan cara melihat kompetensi atau kehadiran penulis tehadap waktu atau peristiwa, kepentingan penulis, sikap berat sebelah serta motif penulis, juga sangat perlu untuk diketahui guna menentukan kredibilitas isi tulisan.

\section{Interpretasi}

Interpretasi adalah proses pemaknaan fakta sejarah. Dalam interpretasi terdapat dua poin penting, yaitu sintesis (menyatukan) dan analisis (menguraikan). Fakta-fakta sejarah dapat diuraikan dan disatukan sehingga mempunyai makna yang berkaitan satu dengan lainnya. Fakta-fakta sejarah harus diinterpretasikan atau ditafsirkan agar sesuatu peristiwa dapat direkonstruksikan dengan baik. (Sejarah, 2013).

Sintesis dalam interpretasi merupakan elemen yang penting karena ketika sumbersumber telah terkumpul, baik itu sumber yang lengkap maupun sumber yang tidak utuh, sekecil apapun sumber yang didapat maka akan memberi secercah petunjuk ke arah interpretasi lebih lanjut. Sumbersumber tersebut kemudian disatukan untuk diinterpretasi apakah dapat dijadikan bahan rekonstruksi sejarah yang kuat.

Selain itu analisis suatu sumber juga tidak boleh luput dari interpretasi, karena analisis inilah yang sebenarnya merupakan esensi dari interpretasi itu sendiri. Analisis berfungsi sebagai penopang rekonstruksi sejarah agar nantinya penelitian tidak mengada-ada, namun berdasar pada argumentasi yang kokoh dan valid sehingga nantinya dalam proses historiografi akan lebih mudah dalam praktiknya.

\section{Historiografi}

Setelah sumber dikritik menjadi data kemudian dimaknai menjadi fakta, langkah terakhir adalah menyusun semuanya menjadi satu tulisan utuh berbentuk narasi kronologis. Pada tahapan ini semua data dari sumber yang telah dikritik dan diinterpretasi kemudian disatukan dalam bentuk tulisan mengenai ekspansi kerajaan Gowa-Tallo ke wilayah Limae Ajatappareng ini. Penulisan harus dilakukan secara hatihati dan cermat berdasarkan data dan fakta hasil penelitian serta harus melalui tahap verifikasi dan interpretasi guna menghasilkan tulisan yang baik dan bermuatan ilmu pengetahuan untuk kemajuan ilmu kesejarahan lokal.

\section{Tinjauan Umum Penelitian}

Tinjauan geografis merupakan sesuatu yang penting untuk memberikan pemahaman mengenai kondisi wilayah yang diteliti. Oleh karenanya, sebelum membahas lebih jauh mengenai Ekspansi Kerajaan Gowa-Tallo ke Limae Ajatappareng abad XVI, maka terlebih dahulu penulis akan sedikit menggambarkan kondisi geografis wilayah tersebut. Selain itu akan ditinjau pula mengenai kondisi sosial dan perekonomian di wilayah-wilayah tersebut.

Limae Ajatappareng merupakan suatu konfederasi yang beranggotakan lima kerajaan yakni, Suppa,Sawitto, Sidenreng Rappang, dan Alitta. Limae Ajatappareng terletak di sebelah barat danau sehingga disebut sebagai Limae Ajatappareng (Lima kerajaan yang terletak di barat danau), di bagian utara berbatasan dengan konfederasi pitu babanna binanga dan konfederasi Massenrempulu, di bagian barat dengan Selat Makassar, dan di selatan berbatasan dengan kerajaan Soppeng dan kerajaan Tanete. (Pabitjara, 2019). Sedangkan kerajaan Gowa-Tallo merupakan gabungan 
dua kerajaan yang terletak di bagian selatan Sulawesi bagian selatan.

Berdasarkan hasil penelitian, maka dapat dilihat produksi utama kerajaankerajaan di Ajatappareng merupakan beras. Selain itu, anggota Limae Ajatappareng juga berfokus pada perdagangan terutama beras dan rempah-rempah. Begitu pula dengan kerajaan Gowa-Tallo yang lebih berfokus pada perdagangan maritim.

Adapun kondisi sosial masyarakat di Limae Ajatappareng maupun di GowaTallo memiliki kesamaan. Kesamaan tersebut dapat dilihat dari kepercayaan masyarakat yang percaya kepada Dewata dan tradisi-tradisi animisme serta segelintir penguasa yang menganut agama kristen sebagai bagian dari hubungan dengan bangsa Portugis yang berkunjung ke Sulawesi pada masa itu.

Untuk memahami lebih lanjut mengenai kondisi kedua pihak tersebut, maka terlebih dahulu perlu diperhatikan gambaran umum dari Limae Ajatappareng dan Kerajaan Gowa-Tallo.

\section{Gambaran Umum Limae Ajatapareng}

Konfederasi Limae Ajatappareng merupakan suatu persekutuan politik yang beranggotakan lima kerajaan di wilayah barat pulau Sulawesi bagian selatan yakni kerajaan Sidenreng, Rappang, Sawitto, Suppa dan Alitta. Pembentukan Konfederasi ini didasarkan pada keinginan untuk meningkatkan kesejahteraan perekonomian masing-masing kerajaan anggota konfederasi. Dapat dipahami pula, bahwa pembentukan Konfederasi ini sebagai bentuk penegasan persatuan dan rasa persaudaraan serta penggalangan kekuatan untuk menghadapi manuver politik dari kerajaan-kerajaan sekitar yang kiranya dapat mengancam kedaulatan kerajaan anggota konfederasi Limae Ajatappareng.

Salah satu sumber mengatakan bahwa Konfederasi Limae Ajatappareng terbentuk pada abad XVI yaitu pada masa pemerintahan La Makkarawie yang merupakan Datu Suppa pada sekitar tahun 1523 M. Pernyataan itu didasarkan pada sumber Lontara' yang bertuliskan “...... Seppulo dua taung rumpa'na arajangnge ri lamalaka, na ripammulani assijanciangnge riasenge limae ajatappareng", yang jika diterjemahkan berbunyi dua belas tahun jatuhnya malaka, dimulainya ikrar yang dinamakan Limae Ajatappareng. (Pabitjara, 2006) Laporan seorang Portugis bernama Antonio de Paiva menguatkan pendapat bahwa Suppa berada dibawah pemerintahan Datu La Makkarawie karena pada tahun 1544 ia sempat berkunjung ke Suppa dan Siang lalu kemudian membaptis Datu Suppa La Makkarawie dan memberi nama Don Joao.

Pembentukan konfederasi ini bertujuan untuk meningkatkan taraf perekonomian dan persaudaraan melalui sistem kekerabatan yang erat. Tidak menutup kemungkinan pula bahwa konfederasi ini juga digunakan sebagai alat politik. Masingmasing kerajaan diberi kebebasan untuk mencari nafkah dan juga saling membantu apabila terdapat kekurangan pada salah satu dari kerajaan tersebut. Perjanjian ini memuat kesepakatan-kesepakatan yang fleksibel sehingga memberikan keleluasaan kerajaan-kerajaan yang bernaung di bawah konfederasi ini untuk melaksanakan jalannya pemerintahan masing-masing.

Pasca terbentuknya Konfederasi, kerajaan-kerajaan semakin leluasa untuk melakukan kawin-mawin politik. Dapat dilihat bahwa La Makkarawie Datu Suppa ke-4 menikahkan anaknya We Lampe Weluwa dengan La Cella Mata dari Sawitto yang juga secara kebetulan merupakan sepupu satu kalinya. Selain itu pernikahan juga dilakukan We Gempo Massaoloccie dari Addatuang Sawitto dengan La Pateddungi Datu Sidenreng. (A. Rasyid Asba, 2015). Pernikahan ini dimaksudkan untuk mempererat hubungan antar kerajaan dan juga sebagai tanda terjalinnya aliansi. Dapat dipahami bahwa kerajaankerajaan di Limae Ajatappareng memanfaatkan pernikahan selain untuk mendapat pewaris takhta kerajaan juga sebagai usaha untuk melanggengkan persekutuan atau bahkan dapat dijadikan 
sebagai transaksi politik kerajaan-kerajaan di Ajatappareng.

Di samping kegiatan perpolitikan secara internal, konfederasi Limae Ajatappareng juga mengadakan kontak-kontak politik dengan dunia luar (Eksternal) yaitu Addatuang Sidenreng yang telah terlebih dahulu menjalin kerjasama militer dengan Kerajaan Gowa-Tallo yang disisi lain menjadi ancaman yang nyata bagi keberlangsungan hidup serta kedaulatan kerajaan-kerajaan Limae Ajatappareng. Suatu hal yang cukup menarik dikarenakan Kerajaan Gowa-Tallo dikemudian hari justru menjadikan anggota persekutuan Limae Ajatappareng sebagai target ekspansinya.

\section{Gambaran Umum Kerajaan Gowa- Tallo}

Kerajaan Gowa merupakan salah satu kerajaan yang telah lama berdiri di Sulawesi Selatan. Namun, detail pasti mengenai kapan terbentuknya kerajaan ini tidak jelas, sebab sumber Gowa tidak memberikan detail yang jelas mengenai kapan munculnya kerajaan ini. Kerajaan ini baru benar-benar muncul dan mulai menarik perhatian sejak Karaeng Tumapa'risi Kallonna (1510-1546) memerintah dan memindahkan pusat kerajaan yang semula berada di Tamalate ke Somba Opu. Pemindahan pusat kerajaan ini turut mengubah orientasi pemerintahan kerajaan Gowa dari agraris menjadi maritim. (Poelinggomang, 2016). Semenjak perubahan orientasi tersebut, Kerajaan Gowa kemudian menjadi kerajaan yang ekspansionis. Terbukti dengan ditaklukkannya Tallo dan wilayah-wilayah sekitarnya. Penaklukan kerajaan Tallo kemudian menjadikan dua kerajaan tersebut menyatu sebagai kerajaan kembar Gowa-Tallo.

Secara ekonomi, pasca pemindahan pusat kerajaan Gowa-Tallo, perekonomian kerajaan turut mengalami kemajuan terutama karena terhubungnya kerajaan Gowa-Tallo dengan jaringan perdagangan internasional. Hal ini ditandai dengan merangkapnya seorang Tumailalang sebagai pejabat bandar niaga Gowa-Tallo. Yang kemudian pada masa pemerintahan Karaeng Tunipallangga dibentuklah jabatan baru dengan memisahkan antara jabatan Tumailalang dengan jabatan baru yang bernama Sabannara'. Dibentuknya jabatan Sabannara' pada masa pemerintahan Karaeng Tunipallangga ini mengindikasikan bahwa bandar kerajaan telah sangat ramai, sehingga dibutuhkan pejabat khusus yang mengatur kepentingan pelayaran dan jalur perdagangan di bandar Gowa-Tallo.

Secara politik, pada abad XVI kerajaan Gowa-Tallo telah menempatkan diri sebagai salah satu kerajaan terbesar dan berpengaruh di Sulawesi Selatan. Hal itu ditunjukkan dengan keberhasilan dalam peperangan dan penaklukan terhadap kerajaan-kerajaan lain. Gowa-Tallo terus melakukan ekspansi dari selatan ke utara Sulawesi bagian selatan. pada paruh akhir abad XVI, Praktis hanya kerajaan-kerajaan besar seperti Luwu dan Bone yang belum dapat ditaklukkan. Selain itu, Gowa-Tallo juga telah berhubungan dengan kerajaan Sidenreng di Ajatappareng dan bersamasama melakukan peaklukan terhadap Otting dan Bulu Cenrana.

\section{Pembahasan}

\section{Latar Belakang Ekspansi Gowa-Tallo Ke Limae Ajatappareng Abad XVI}

Ekspansi adalah kegiatan yang dilakukan untuk memperluas kekuasaan baik dalam hal wilayah maupun perekonomian. Limae Ajatappareng telah dikenal sebagai pengontrol jalur perdagangan di barat Sulawesi Selatan sehingga menarik minat kerajaan-kerajaan lain untuk menguasainya, termasuk kerajaan Gowa-Tallo. Latar belakang ekspansi kerajaan Gowa-Tallo ke Limae Ajatappareng dapat dilihat sebagai berikut:

\section{a. Ambisi Gowa-Tallo menguasai perdagangan}

Kerajaan Gowa-Tallo dibawah kekuasaan Karaeng Tumapa'risi Kallonna sedari awal pemindahan pusat pemerintahan kerajaan dari Tamalate ke 
Somba Opu di muara sungai Jeneberang telah memiliki ambisi dan niatan untuk membuka diri terhadap dunia luar. Hal ini tentunya menjadikan kerajaan Gowa-Tallo terlibat secara langsung dalam jaringan perdagangan dunia. Tanda kesiapan GowaTallo untuk terjun langsung terhadap persaingan perdagangan global adalah dengan dibentuknya jabatan Syahbandar dalam struktur pemerintahan, yang bertugas mengatur pelayaran dan pajak perdagangan di bandar Somba Opu. (Hamid, 2015).

Kerajaan Gowa-Tallo sebenarnya memiliki peluang yang sangat besar untuk memuluskan ambisi mengembangkan bandar Kerajannya. Setidaknya hal ini karena usaha tersebut didukung oleh tiga faktor yakni: (Poelinggomang, 2004).

1. Letaknya yang strategis karena posisinya berada di tengah-tengah dunia perdagangan

2. Intervensi bangsa Eropa dalam dunia niaga telah memberikan peluang bagi pedagang-pedagang di pusat niaga yang mengitarinya mengalihkan kegiatan mereka ke Makassar. Setelah Malaka dikuasai Portugis tahun 1511, terjadi perpindahan besar-besaran para saudagar Melayu ke timur, yakni Kalimantan dan Sulawesi. Kemudian diikuti dengan keberhasilan VOC menguasai pelabuhan-pelabuhan di Pantai Utara Jawa. Peluang itu dimanfaatkan oleh Kerajaan Makassar untuk membangun bandar dan mengembangkan perdagangan maritim.

3. Peranan penduduk di daerah sebagai pedagang dan pelaut yang melakukan pelayaran niaga ke daerah-daerah produksi dan bandar niaga lain, yang kemudian memperdagangkannya ke bandar Makassar.

Namun, ambisi tersebut terganjal oleh Kerajaan-kerajaan di utara Sulawesi bagian selatan. Terlebih setelah kerajaan-kerajaan tersebut terhimpun ke dalam persekutuan Limae Ajatappareng. Selain itu, para pedagang pasca jatuhnya Malaka pada tahun 1511 lebih memilih untuk mengalihkan kegiatan perdagangan mereka ke Suppa dan Siang dibanding ke bandar Gowa-Tallo. Para pedagang ini menjalankan perdagangan dengan cara menetap dan mendirikan komunitaskomunitas pedagang melayu muslim di sepanjang pantai barat Sulawesi Selatan terutama di wilayah Suppa, Siang, dan Mandar. Agar kerajaan Gowa-Tallo dapat mencapai ambisinya, maka Kerajaan GowaTallo harus menguasai Suppa dan Siang terlebih dahulu. (Pabitjara, 2019).

\section{b. Limae Ajatappareng sebagai pesaing Gowa-Tallo}

Limae Ajatappareng sebagai suatu konfederasi atau persekutuan yang muncul pada abad ke-XVI telah mengubah pandangan geopolitik di kawasan Sulawesi bagian Selatan. Memandang pentingnyapersekutuan ini dalam konstalasi politik di Sulawesi Selatan, agar kiranya kerajaan-kerajaan di wilayah ini sepatutnya diperhatikan kondisi-kondisi terkini pasca pembentukan Konfederasi Limae Ajatappareng yakni:

1. Lokasi geografis yang sewaktu-waktu dapat berubah sesuai dengan kesepakatan atas suatu perjanjian tertentu.

2. Besar atau kecilnya suatu Kerajaan yang termasuk di dalamny

3. Topografi wilayah, demografi, sumber daya alam, dan perkembangan teknologi di kerajaan-kerajaan tersebut

4. Kekuatan militer dan sumber daya manusia di Limae Ajatappareng dan kerajaaan-kerajaan sekitarnya.

Apabila dilihat dari variabel-variabel tadi, maka dapat dianalisis bahwa Limae Ajatappareng sudah mumpuni untuk menjadi pesaing atau rival kerajaan ambisius Gowa-Tallo terutama kerajaankerajaan seperti Suppa, Sidenreng, dan Sawitto. 
Gambaran mengenai kekuatan Suppa dan Sawitto dapat dilihat dari surat Paiva yang mengatakan bahwa ia telah tiba di pelabuhan Suppa yang dipimpin oleh orang yang sangat gemar berperang dan sangat ditakuti di daerah tersebut. Selain itu, dalam beberapa sumber didapati bahwa kerajaan Suppa memiliki Bate (Bendera) yang bernama Lasigalung (Persawahan) yang sangat besar dan memiliki empat kaki. Setiap tanah yang dilalui oleh bendera tersebut dapat dikalahkan oleh kerajaan Suppa. (Druce, 2009)

Selain Suppa dan Sawitto, Sidenreng juga memiliki kekuatan yang cukup besar bila dibandingkan dengan kerajaan-kerajaan di Ajatappareng. Kekuatan Sidenreng disokong oleh kerajaan-kerajaan vasal mereka yakni Maiwa, Otting, dan Bulucenrana. (Caldwell, 1988). Maiwa merupakan salah satu vasal yang paling dekat dengan Sidenreng, tugasnya adalah untuk menyediakan pasukan serta bantuan militer kepada kerajaan Sidenreng.

Tentunya, dengan kekuatan militer yang besar, armada laut yang tangguh serta cakupan wilayahnya yang luas, Kerajaan Suppa dan Sawitto serta kerajaan-kerajaan Ajatappareng lainnya sudah mumpuni untuk menghalau politik ekspansional yang gencar dilakukan oleh Kerajaan GowaTallo pasca bersatunya dua kerajaan tersebut serta munculnya kerajaan GowaTallo sebagai kerajaan besar yang siap untuk menunjukkan eksistensi dan hegemoninya ke kerajaan-kerajaan lain di Sulawesi Selatan.

\section{c. Limae Ajatappareng sebagai Lumbung Pangan}

Ajatappareng jika dilihat dari segi geografis, memiliki kondisi alam yang bermacam-macam. Di sebelah barat terdapat lautan, di utara memiliki pegunungan yang menjulang tinggi, di sebelah timur terdapat Danau besar yakni Sidenreng dan Tempe, serta sungai Saddang yang mengalir di tengahtengahnya. Kondisi alam yang beraneka ragam menjadikan ajatappareng sebagai wilayah strategis terutama dalam hal ketersediaan pangan. Keuntungan spasial yang diperoleh dapat dimanfaatkan untuk kegiatan pertanian dan peternakan, sesuatu yang dapat dimanfaatkan dengan baik oleh kerajaan-kerajaan Ajatappareng.

Keuntungan secara geografis ini dapat dimanfaatkan dengan baik oleh kerajaankerajaan di Ajatappareng. Kerajaan Suppa yang merupakan salah satu kerajaan tua di Sulawesi Selatan telah tercatat di dalam catatan kerajaan Majapahit, hal ini disebabkan sungai mereka yang terhubung langsung ke danau besar di Sidenreng yang digunakan oleh orang-orang Majapahit yang mencari besi ke tanah Luwu. Selain itu, keuntungan ini juga dimanfaatkan oleh kerajaan Alitta dengan menggunakan aliran sungai untuk mendistribusikan barangbarang dagangan dari Sidenreng ke bandar niaga Suppa.

Sawitto memiliki areal persawahan yang sangat luas. Seperti di sekitar pusat kerajaan, kebanyakan lahan dibuka hanya untuk kawasan persawahan. (Druce, 2009) Sejumlah wilayah bawahan Sawitto seperti Tiroang, Rangamea, Loloang, dan Langnga juga memiliki areal persawahan yang luas. Selain padi, Sawitto dan daerah bawahannya juga memproduksi tanaman pangan lain seperti ubi, kacang, dan wijen.

Sama halnya dengan Sawitto, Sidenreng dan Rappang juga merupakan penghasil beras, bahkan Sidenreng pada abad ke XV mampu menghasilkan kekayaan produk agrikultural yang meningkat tajam dan berhasil mencapai surplus beras. Hasilnya kemudian disalurkan ke Alitta. Alitta sedikit berbeda dari kerajaan-kerajaan Ajatappareng lainnya, karena Alitta tidak menjadikan tanaman padi sebagai komoditas utama. Keahlian utama Kerajaan Alitta yakni mengontrol jalur perdagangan dari Sidenreng, Suppa, dan Sawitto yang secara langsung juga meningkatkan kekayaan kerajaan kecil ini. (Druce, 2009). Suppa sebagai kerajaan pesisir tentunya lebih banyak berfokus kepada hasil pangan dalam sektor perikanan dibandingkan tanaman pangan. Sehingga komoditas utama kerajaan Suppa yakni ikan yang 
ditangkap dari perairan sekitar Suppa. Namun tidak dapat dipungkiri pula bahwa kerajaan Suppa juga menghasilkan beras dan berbagai macam tanaman pangan, walaupun jumlahnya tentu tidak sebesar kerajaan pedalaman seperti Sawitto dan Sidenreng.

Dengan kekayaan sumber pangan yang melimpah ruah, Ajatappareng menjadi incaran kerajaan Gowa-Tallo yang pada saat itu sedang berambisi menjadi kerajaan besar dengan praktik ekspansionalnya yang tentunya harus didukung oleh ketersediaan pangan dan Ajatappareng diharapkan mampu memenuhi semua kebutuhan tersebut.

\section{Bentuk-Bentuk Ekspansi Kerajaan Gowa Tallo Ke Limae Ajatappareng}

Ekspansi yang dilakukan oleh kerajaan Gowa-Tallo ke Limae Ajatappareng bukan semata-mata dilakukan untuk memperluas wilayah kerajaannya saja, tetapi juga didasari oleh keinginan untuk meningkatkan perekonomian kerajaan serta untuk menancapkan pengaruh yang lebih dalam kepada kerajaan-kerajaan lain dengan cara perkawinan politik.

\section{a. Perang Suppa dan Sawitto melawan Gowa-Tallo}

Abad ke XVI masa dimana banyaknya kerajaan di Sulawesi Selatan yang mulai nampak kekuatannya dan muncul dengan status "New Emerging Force" serta kekuatan-kekuatan lama yang berusaha mempertahankan eksistensinya. Kerajaan Gowa-Tallo yang baru saja muncul dengan tampilan sebagai dua kerajaan kembar dan berorientasi maritim berusaha untuk berpartisipasi aktif dalam perpolitikan lokal Sulawesi Selatan terutama dalam hal ekspansi. Kerajaan Gowa-Tallo dari masa kekuasaan Karaeng Tumapa'risi Kallonna hingga Karaeng Tunipallangga menjadi salah satu yang paling aktif menjalankan kegiatan ekspansinya.

Keberhasilan Gowa-Tallo menguasai wilayah-wilayah sekitarnya dengan gemilang seakan belum lengkap apabila belum menguasai jalur perdagangan yang mana merupakan ambisi utama mereka. Di utara,
Kerajaan Suppa telah menguasai jalur perdagangan laut timur Nusantara pasca jatuhnya Malaka pada tahun 1511.Untuk menguasai jalur perdagangan tentunya Kerajaan Gowa-Tallo harus menaklukkan Suppa. Namun, sebelum melakukan serangan ke Suppa, kerajaan-kerajaan di wilayah tersebut telah terlebih dahulu bergabung menjadi Konfederasi Limae Ajatappareng. Persekutuan tersebut menandakan jika ingin menaklukkan Suppa, Gowa-Tallo harus menghadapi empat anggota konfedrasi yang lain sekaligus. Ketidakseimbangan dalam jumlah membuat Karaeng Tunipallangga harus berpikir ulang, dan cara yang paling halus dalam suatu politik ekspansi adalah melalui jalur perkawinan politik.

Karaeng Tunipallangga kemudian mencoba menikahkan salah satu putranya dengan putri dari kerajaan Suppa yang bernama We Lampeweluwa, dan kemudian diterima oleh Datu Suppa La Makkarawie. Namun, tiba-tiba datang pula lamaran dari kerabat mereka dari Sawitto yang ingin menikahkan La Cella' Mata putra La Paleteang Datu Sawitto dengan putri Datu Suppa tersebut. La Makkarawie pun menerima lamaran tersebut dengan pertimbangan mereka lebih mengenal Sawitto dibanding Gowa-Tallo. Mendengar bahwa lamaran dari Sawitto diterima, maka Karaeng Tunipallangga marah sebab ia telah dipermalukan (Siri). Maka terjadilah perang antara Gowa-Tallo menghadapi Suppa' dan Sawitto (juga Alitta) yang berlangsung selama tujuh tahun. Dimana setiap tahun dihitung sebagai jadwal penyerangan. Pada serangan ketujuh kalinya kerajaan Suppa' dan Sawitto akhirnya dapat ditaklukkan. Setelah penaklukan maka dibawalah orang-orang Sawitto dan Suppa ke Gowa. Dalam rombongan tersebut terdapat La Paleteang Datu Sawitto, La Cella' Mata, dan We Lampe' Welua.

Pasca kekalahan tersebut, maka Karaeng Tunipallangga memerintahkan untuk mengangkut orang-orang dari Suppa dan Sawitto. Termasuk La Paleteang, La 
Cella' Mata, dan We Lampe Welua. Pasangan suami-istri La Cella' Mata dan We Lampe Welua disiksa hingga dibunuh sedangkan La Paleteang dibiarkan hidup hingga akhirnya dikembalikan ke tanah Sawitto. Kerajaan Gowa-Tallo turut mengangkut orang-orang Melayu yang diduga sebagai ahli dalam bidang perdagangan.

\section{b. Penguasaan Ekonomi}

Pasca penaklukan Suppa dan Sawitto oleh Gowa-Tallo, maka praktis kegiatan perekonomian dialihkan ke bandar Gowa. Peralihan tersebut dibuktikan dengan menjamurnya pemukiman pedagang asing di sekitar Kerajaan Gowa-Tallo. Oleh karena itu, dapat dikatakan bahwa Suppa' dan Sawitto tidak hanya kalah dalam peperangan tetapi juga menderita kekalahan dalam hal perekonomian. Kekalahan ini juga mengakhiri persaingan antara kerajaan ini untuk menguasai jalur perdagangan bagian timur.

Kerajaan Gowa-Tallo senantiasa mengangkut pedagang dari setiap kerajaan taklukan yang dianggapnya potensial. Selain itu Gowa-Tallo juga menerapkan penghancuran bandar-bandar yang membuat kerajaan taklukan tidak dapat mengembangkan lagi bandar niaganya. Pengaruh langsung dari kebijakan tersebut memaksa para pedagang untuk memindahkan kegiatan operasional mereka ke Gowa-Tallo. (Poelinggomang, 2016). Takluknya Suppa dan Sawitto juga memberi akses bagi Gowa-Tallo terhadap ketersediaan pangan yang cukup untuk memenuhi kebutuhannya. Seperti yang diketahui sebelumnya bahwa kerajaan di Limae Ajatappareng merupakan penghasil sumber pangan yang melimpah. Keuntungan dari penaklukan tersebut ialah Gowa-Tallo dapat menjaga ketahanan dan stabilitas pangan sebagai penopang keberlangsungan bandar besar Gowa-Tallo. Selain itu komoditas beras yang melimpah juga dapat dijadikan alat barter untuk benda-benda dari luar.

c. Perkawinan Politik
Perkawinan dalam kerajaan BugisMakassar merupakan sesuatu yang sangat penting. Pentingnya perkawinan dapat dilihat dari seleksi calon mempelai yang cukup rumit maupun kepentingankepentingan yang biasanya berada di belakang maksud dari perkawinan kerajaan tersebut. Tujuan dari perkawinan kerajaan selain untuk mengawinkan putra-putri kerajaan juga biasanya untuk mengawinkan kerajaan demi mengamankan persekutuan maupun menjalin hubungan dan mempertahankan hubungan-hubungan yang telah terjalin sebelumnya.

Kerajaan Suppa yang mengalami kekosongan pemangku kekuasaan pasca dikalahkannya Suppa dan Sawitto. Kekosongan ini disebabkan oleh pembunuhan We Lampe' Welua oleh Karaeng Gowa Tunipallangga. Melihat kekosongan tersebut maka Karaeng Tunipallangga berinisiatif untuk mendudukkan putrinya pada tahta kerajaan Suppa. Putrinya tersebut bernama We Tosappai, yang diberi gelar Karaeng Baineya sebagai Datu Suppa ke-6.

Untuk memuluskan langkah politik Karaeng Tunipallangga di tanah Ajatappareng, maka ia memutuskan untuk mengawinkan We Tosappai dengan La Patiroi Datu Sidenreng ke-6. Perkawinan ini dapat dikatakan sebagai langkah politik yang cukup tepat karena dengan menghubungkan darah mereka maka akan sedikit meredam gejolak di masyarakat bawah terhadap kepemimpinan yang "tidak sah”. Diketahui bahwa perkawinan We Tosappai dengan La Patiroi berhasil menyambung tali kekerabatan antara Gowa-Tallo, Suppa, Sidenreng, dan Sawitto. Perkawinan tersebut akan menambah legitimasi kekuasaan GowaTallo di Ajatappareng sekaligus berhasil untuk mengokohkan posisi terhadap wilayah yang telah sukses mereka kuasai. Maka dengan cara ini, Gowa Tallo berhasil mengukuhkan pengaruh di Limae Ajatappareng dan keberhasilan ini merupakan pencapaian yang menakjubkan 
dalam meredam gejolak di masyarakat Ajatappareng.

\section{Dampak Ekspansi Kerajaan Gowa- Tallo ke Limae Ajatappareng}

Ekspansi yang dilakukan oleh Kerajaan Gowa-Tallo melalui penaklukan, penguasaan ekonomi, dan perkawinan politik memberikan dampak positif dan negatif bagi masing-masing pihak. Di satu sisi kerajaan Gowa-Tallo sebagai pemenang dalam peperangan berhak untuk menguasai kerajaan taklukannya dan pihak yang kalah harus menanggung semua kerugian yang ditimbulkan setelah berakhirnya peperangan.

\section{a. Bagi Ajatappareng}

Dampak ekspansi dari kerajaan GowaTallo sangat dirasakan oleh kerajaankerajaan Limae Ajatappareng. Ekspansi tersebut banyak mengubah tatanan hidup masyarakat Ajatappareng, terutama kerajaan yang terlibat dalam peperangan melawan Gowa-Tallo. Dampak ekspansi itu dapat dilihat utamanya dalam bidang politik dan ekonomi Limae Ajatappareng. Ekspansi Gowa-Tallo kebanyakan membawa penderitaan bagi Limae Ajatappareng. Dunia politik Sulawesi Selatan menjadi sektor yang cukup terdampak pasca penaklukan Ajatappareng. Suppa dan Sawitto yang dahulu berkuasa hampir di sepanjang pantai barat Sulawesi harus melepas wilayah-wilayah bawahan mereka.

Secara ekonomi jika dilihat pada umumnya penaklukan Gowa-Tallo terhadap Limae Ajatappareng tidak terlalu mempengaruhi kegiatan perekonomian di wilayah tersebut. Para pedagang tetap melakukan kegiatan perdagangan. Pedagang di kawasan Ajatappareng kebanyakan merupakan pedagang beras dan pengumpul rempah-rempah hingga menjangkau bandar-bandar niaga lain di Nusantara. (Pabitjara, 2006)

Satu hal yang membuat perekonomian Suppa melemah adalah dialihkannya bandar perdagangan laut Sulawesi bagian Selatan dari Suppa ke Gowa-Tallo. Perpindahan bandar perdagangan laut dari
Suppa ke Gowa-Tallo membuat orangorang Melayu yang cakap dalam berdagang turut berpindah mengikuti perpindahan bandar niaga tersebut. Hal itu membuat bandar yang dahulu ramai oleh pedagang perlahan-lahan menjadi sepi akan kehadiran pedagang-pedagang, terutama pedagang asing. Namun, perlu dicatat bahwa penurunan jumlah pedagang di kawasan secara drastis tidak serta merta berarti kelumpuhan perekonomian secara total. Hingga berabad-abad kebelakang Ajatappareng tetap dikenal sebagai penghasil pangan melimpah terutama pada komoditas beras.

\section{b. Bagi Gowa-Tallo}

Penaklukan Gowa-Tallo terhadap Limae Ajatappareng berimplikasi sangat besar terhadap kelanjutan ekspansi yang dilakukan di Sulawesi Selatan. Ditaklukannya Limae Ajatappareng secara praktis membuat Gowa-Tallo kehilangan rival yang dapat menjegal potensi dan ambisi Gowa-Tallo untuk menjadi bandar niaga besar di bagian timur Nusantara. Secara politik, Gowa-Tallo telah berhasil memperlihatkan dirinya ke dunia internasional dan meningkatkan prestisenya di mata para pesaingnya di Sulawesi Selatan.

Hasil yang didapat kerajaan Gowa-Tallo setelah berhasil menaklukkan Limae Ajatappareng adalah penguasaan mereka terhadap Sumber Daya Manusia (SDM) yang terampil dalam pembuatan perahu. Orang-orang inilah yang diindikasikan sebagai rakyat Suppa dan Sawitto yang turut diangkut oleh Gowa-Tallo. Mereka ditempatkan di sekitaran benteng Somba Opu bersama orang-orang Mandar yang juga merupakan ahli dalam pembuatan perahu. (Pabitjara, 2006). Keterampilan orang-orang Suppa dan Mandar ini sangat dibutuhkan oleh Kerajaan Gowa-Tallo dalam rangka persiapan mereka untuk menjadi bandar niaga terbesar di Nusantara bagian timur menggantikan kerajaan Suppa.

Penguasaan terhadap perdagangan secara otomatis membuat Gowa-Tallo juga menguasai komoditas-komoditas yang 
bernilai tinggi di pasaran internasional. Beras, rempah-rempah, dan kayu Cendana menjadi komoditas yang cukup bernilai pada masa itu.Beras-beras dapat dijadikan sebagai penopang kebutuhan konsumsi masyarakat serta pedagang-pedagang internasional. Di setiap kota-kota besar tentunya membutuhkan pasokan beras yang mencukupi. Apabila kebutuhan pangan bisa terpenuhi, maka jalannya perniagaan di bandar Gowa-Tallo sebagai bandar dapat terlaksana dengan lancar dan menjadikan Gowa-Tallo sebagai kota besar dan kaya. Selain beras, rempah-rempah dan kayu cendana juga menjadi barang dagangan yang bernilai tinggi. Perdagangan rempahrempah yang menjadi barang yang bernilai tinggi di pasar internasional kini berpindah ke bandar niaga Gowa-Tallo. Rempahrempah yang banyak diproduksi di kepulauan Maluku diperdagangkan di bandar Gowa-Tallo untuk kemudian diekspor kembali ke bandar-bandar lain sebagai imbas dari perkembangan bandar Gowa-Tallo yang semakin ramai oleh pedagang. Bandar niaga di kerajaan GowaTallo yang menjadi bandar transit perdagangan rempah-rempah dari Maluku ke Malaka menjadikan bandar Gowa-Tallo ramai oleh pedagang. Ramainya pedagang secara tidak langsung dapat meningkatkan perekonomian kerajaan.

Keuntungan dari penguasaan jalur niaga laut Nusantara timur memberi dampak yang amat besar bagi kemajuan kerajaan Gowa-Tallo. Keuntungan tersebut bahkan menjadikan kerajaan Gowa-Tallo berkembang pesat, terutama karena ramainya kegiatan perdagangan dan kehadiran pedagang-pedagang internasional. Hubungan antara pedagangpedagang dan kerajaan yang memasarkan produknya di bandar Gowa-Tallo saling menguntungkan mengingat bahwa Kerajaan Gowa-Tallo tidak memungut pajak atas perdagangan barang-barang yang tidak termasuk dalam kategori barang mewah.

Ramainya bandar Gowa-Tallo merupakan buah dari usaha raja-raja GowaTallo terdahulu terutama pada masa pemerintahan Karaeng Tumapa'risi Kallonna dan Karaeng Tunipallangga pada abad XVI yang terus berusaha untuk memperluas dan menunjukkan eksistensi kerajaannya sebelum kemudian kejatuhan bandar niaga besar tersebut ke tangan $V O C$ di abad XVII.

\section{E. Kesimpulan}

Limae Ajatappareng merupakan suatu konfederasi beranggotakan Suppa, Sawitto, Sidenreng, Rappang, dan Alitta. Konfederasi yang lebih berfokus pada peningkatan perekonomian masing-masing kerajaan merupakan pesaing utama bagi ambisi Gowa-Tallo untuk menguasai perdagangan di pantai barat Sulawesi. Selain itu Ajatappareng sebagai lumbung pangan sangat menarik untuk dikuasai sumber daya alamnya. Maka untuk menguasai Limae Ajatappareng, kerajaan Gowa-Tallo menggunakan tiga cara yakni, perang, penguasaan ekonomi, dan perkawinan politik. Perang yang terjadi selama tujuh tahun menghasilkan GowaTallo sebagai pemenangnya dan menjadikan Limae Ajatappareng sebagai bawahannya sehingga kemudian berusaha menguasai perekonomian dengan memindahkan pedagang-pedagang di Suppa menuju bandar Gowa-Tallo. Selain itu, perkawinan politik juga dilakukan kerajaan Gowa-Tallo untuk menancapkan pengaruhnya di Limae Ajatappareng. Keberhasilan Gowa-Tallo menaklukkan Limae Ajatappareng memberikan dampak bagi masing-masing pihak. Bagi Limae Ajatappareng ekspansi Gowa-Tallo dan penaklukan yang dilakukan menjadikan Limae Ajatappareng melemah baik dalam kekuatan militer maupun perekonomian sedangkan bagi kerajaan Gowa-Tallo, keberhasilan mereka menaklukkan Limae Ajatappareng membuat kerajaan GowaTallo dapat memajukan bandar kerajaannya dan berhasil mengamankan suplai pangan yang banyak diproduksi di Ajatappareng. 


\section{DAFTAR PUSTAKA}

Rasyid Asba, d., 2015. Silsilah Kekerabatan Raja-raja Sulawesi Selatan-Barat. Jakarta: Buku Pintar Indonesia.

Andaya, L. Y., 2004. Warisan Arung Palakka : Sejarah Sulawesi Selatan. Makassar: Ininnawa.

Anon., 2019. [Online].

Caldwell, I., 1988. South Sulawesi A.D. 1300-1600: Ten Bugis Texts. Canberra: Australia National University.

Druce, S. C., 2009. The Lands West Of The Lakes : A history of the Ajatappareng kingdom of south Sulawesi 1200 to 1600 CE. Leiden: KITLV Press.

Hamid, A. R., 2015. Sejarah Maritim Indonesia. Yogyakarta: Ombak.

Kila, S., 2004. Kerajaan Gowa Tahun 16691799, Kumpulan Laporan Penelitian Pada Kerajaan Gowa Pascaperjanjian Bungaya., Makassar: Kementerian Kebudayaan dan Pariwisata Deputi Bidang Pelestarian dan Pengembangan Kebudayaan Balai Kajian Sejarah dan Nilai Tradisional.

Makmur, M., 2015. Masa Awal Hingga Berkembangnya Kerajaan Ajatappareng (Abad 14-18). Dalam Purbawidya Vol. 4 No. 2, pp. 125136.

Pabitjara, B., 2006. Persekutuan Limae Ajatappareng Abad XVI. Makassar: Universitas Negeri Makassar.

Pabitjara, B., 2019. Letak Geografi [Wawancara] (Senin 7 2019).

Pabitjara, B., 2019. Politik di Sulawesi Selatan [Wawancara] (Senin 7 2019).

Poelinggomang, E. L., 2004. Perdagangan Maritim Masyarakat Sulawesi Selatan. Dalam: Kontinuitas dan perubahan. Yogyakarta: Ombak, pp. 41-58.

Poelinggomang, E. L., 2016. Makassar Abad XIX : Studi Tentang
Kebijakan Perdagangan Maritim. Jakarta: KPG (Kepustakaan Populer Gramedia).

Ratna, N. K., 2010. Metodologi Penelitian : Kajian Budaya dan Ilmu Sosial Humaniora Pada Umumnya. Yogyakarta: Pustaka Pelajar.

Sejarah, T. P. J. P., 2013. Pengantar Ilmu Sejarah. Makassar: Balai Penerbit UNM 